This document is the accepted manuscript version of the following article:

Poulikakos, L. D., \& Hofko, B. (2020). A critical assessment of stiffness modulus and fatigue performance of plant produced asphalt concrete samples using various test methods. Road Materials and Pavement Design, 1-13. https://doi .org/10.1080/14680629.2020.1785927

\title{
A critical assessment of stiffness modulus and fatigue performance of plant produced asphalt concrete samples using various test methods
}

\author{
Authors: Lily D. Poulikakos *a; Bernhard Hofkob \\ * Corresponding author \\ a Empa, Swiss Federal Laboratories for Materials Science and Technology, Überlandstrasse 129, \\ 8600 Dübendorf, Switzerland \\ lily.poulikakos@empa.ch \\ b Technische Universität Wien, IVWS - Institut für Verkehrswissenschaften; \\ bernhard.hofko@tuwien.ac.at
}

\begin{abstract}
This project tested eight commonly used mixtures in Switzerland: three surface courses, three binder courses and two base courses. Three types of test methods for stiffness modulus EN 12697-26 and fatigue resistance EN 12697-24 were used:

Namely, four Point Bending with prismatic sample (4PB-PR), Indirect Tensile test on cylindrical samples with pulse load form (IT-CY) and cyclic load form (CIT-CY). A total of 303 prismatic and cylindrical samples were prepared and tested. It was shown that the test procedures do not deliver the same results, both in terms of value and ranking. This is on the one hand due to the loading mechanisms and on the other due to the type testing parameters of temperature and frequency defined in the European standards. Regarding stiffness, the trend and ranking of the materials for two of the three methods (4PB-PR and CIT-CY) is similar for a majority of tested mixtures, regardless of the temperatures and frequencies used. IT-CY tests performed on eight mixtures did not show sensitivity to the mixture type as much as the 4PB-PR and CIT-CY tests that use a sinusoidal continuous force application. The fatigue resistance data shows that the ranking of the two types of tests (4PB-PR and CIT-CY) for the eight mixtures tested was not the same. 4PB-PR tests induce bending and therefore are a more realistic indication of fatigue induced in the samples.
\end{abstract}

Keywords: Stiffness modulus; Fatigue; Asphalt; 4PB-PR, IT-CY; CIT-CY

\section{Introduction}

Stiffness modulus and fatigue performance of asphalt concrete are key performance parameters to assess mixtures (Nejad 2010; Pasetto 2011, Poulikakos 2014). Although still not a requirement in many countries, these data are the crucial input parameters for several design 
methods such as the mechanistic-empirical pavement design methods (MEPDG) (Eberhardsteiner and Blab 2017). The European standards specify methods for characterizing the stiffness (i.e. modulus) of bituminous mixtures by alternative tests, including bending tests and direct and indirect tensile tests (EN 12697-24, EN 12697-26). The data can be obtained through laborious time consuming tests and are performed on compacted bituminous mixtures under a sinusoidal loading or other controlled loading, using different types of specimens and supports. The procedure is used to rank bituminous mixtures on the basis of stiffness modulus, as a guide to rank relative performance of the pavement and for obtaining data for estimating the structural behavior in the road. As these standards do not impose a particular type of testing device, the precise choice of the test conditions depends on the possibilities and the working range of the used device.

In general there is a lack of comparative data for the specified methods. A RILEM international comparative study was done in 1998; an excerpt of which pertaining to 4PB tests among three European laboratories is shown in Table 1. It can be seen that the difference in the results is as expected, temperature and frequency dependent, and a maximum of $10 \%$ and $18 \%$ in modulus and in phase angle was reported respectively.

Table 1 Stiffness modulus and phase angle results from a RILEM study with three labs (Francken 1998)

\begin{tabular}{|c|c|c|c|c|c|c|c|c|c|c|}
\hline \multirow[t]{2}{*}{$\begin{array}{l}\text { Lab } \\
\text { code }\end{array}$} & \multirow[t]{2}{*}{$\begin{array}{l}\text { Test } \\
\text { type }\end{array}$} & $\begin{array}{l}\text { Spec } \\
\text { Type }\end{array}$ & \multicolumn{4}{|c|}{ Stiffness Modulus E* [MPa] } & \multicolumn{4}{|c|}{$\begin{array}{l}\text { Phase angle } \phi \\
\text { [MPa] }\end{array}$} \\
\hline & & $\begin{array}{l}\text { Temp } \\
{\left[{ }^{\circ} \mathrm{C}\right] /} \\
\text { Freq }[\mathrm{Hz}]\end{array}$ & $0 / 1$ & $0 / 10$ & $20 / 1$ & $20 / 10$ & $0 / 1$ & $0 / 10$ & $20 / 1$ & $20 / 10$ \\
\hline NL2 & $4 \mathrm{~PB}$ & PR & 12219 & 16507 & 2130 & 4794 & 14.9 & 11.1 & 36 & 29.3 \\
\hline NL4 & $4 \mathrm{~PB}$ & PR & 13303 & 16952 & 2814 & 5683 & 10.4 & 8.3 & 31.1 & 24.7 \\
\hline \multirow[t]{4}{*}{ NL5 } & $4 \mathrm{~PB}$ & PR & 13500 & 17269 & 2874 & 5282 & & & & \\
\hline & Avg. & & 13007 & 16909 & 2606 & 5253 & 12.65 & 9.7 & 33.55 & 27 \\
\hline & $\begin{array}{l}\text { Diff. } \\
\%\end{array}$ & & 493 & 360 & 268 & 430 & 2 & 1 & 2 & 2 \\
\hline & diff & & 4 & 2 & 10 & 8 & 18 & 14 & 7 & 9 \\
\hline
\end{tabular}


Another international inter-laboratory test by RILEM, using 11 different test methods, comprising uniaxial tension/compression, 2-, 3- and 4-point bending and indirect-tension tests, investigated fatigue characteristics of a dense graded asphalt concrete mixture. The testing conditions specified were sinusoidal excitation at $10 \mathrm{~Hz}$ and $10^{\circ} \mathrm{C}$ using controlled strain and stress modes. In total, more than 150 fatigue tests were carried out. The results were analyzed using both classical as well as continuum damage mechanics approaches. The test results obtained using the classical fatigue approach are considerably influenced by test type and mode of loading (controlled stress or strain) used. Consequently, the authors concluded that this approach has limited use in realistic fatigue characterization of bituminous materials and pavement structures. They further recommended that in contrast to the classical approach, models founded on continuum damage theory may serve to isolate intrinsic fatigue characteristics from the influence of so-called biased effects, which are largely caused by the accelerated laboratory testing. The continuum damage models investigated may constitute steps, towards a rational mechanistic fatigue characterization model, which are important for effective future pavement design (Di Benedetto, de La Roche et al. 2004).

A study by the author has investigated several materials from Swiss motorways (Poulikakos, Pittet et al. 2014). A total of 252 experiments were performed on eight types of mixtures cut from Swiss motorways at various states of aging. Stiffness tests to determine stiffness modulus were performed at $10^{\circ} \mathrm{C}, 15^{\circ} \mathrm{C}$ and $20^{\circ} \mathrm{C}$ each at 3,10 and $25 \mathrm{~Hz}$ frequency. Fatigue tests were performed at $10^{\circ} \mathrm{C}$ and $25 \mathrm{~Hz}$ for $2 \mathrm{~PB}-\mathrm{TR}$ tests and $20^{\circ} \mathrm{C}$ and $25 \mathrm{~Hz}$ for 4PB-PR tests. The results indicate that although there is more scatter in the 4PB results, stiffness modulus results were similar. However, fatigue resistance values obtained using 4PB and 2PB were not similar in each case studied.

As a result of the intrinsic bias in the test methods some countries have opted for developing requirements for modulus and fatigue performance for each test method. For example, in Hungary different requirements have been developed for different test methods (Table 
2, Puchard \& Gorgenyi 2012). Whereas, in France minimum and maximum values are defined as shown in Table 3. In Austria, there are no limits for stiffness values in the respective specifications but the stiffness value from $4 \mathrm{~PB}-\mathrm{PR}$ at $20^{\circ} \mathrm{C}$ and $8 \mathrm{~Hz}$ has to be reported. Regarding fatigue resistance parameter $\varepsilon 6$, defined as the strain corresponding to one million cycles, Austrian specifications set limit of $\varepsilon 6$ values from $4 \mathrm{~PB}-\mathrm{BR}$ at $20^{\circ} \mathrm{C}$ and $30 \mathrm{~Hz}$ for binder and base layers. For binder layers, a minimum $\varepsilon 6$ of $130 \mu \mathrm{m} / \mathrm{m}$ and for base layer, a highly fatigue resistance class with a minimum $\varepsilon 6$ of $190 \mu \mathrm{m} / \mathrm{m}$ and a standard fatigue resistance class with a minimum $\varepsilon 6$ of $130 \mu \mathrm{m} / \mathrm{m}$ are defined.

Table 2 Hungarian Stiffness and fatigue requirements of AC 16/22 binder (NM) asphalt mixes (Puchard \& Gorgenyi 2012)

\begin{tabular}{llll}
\hline Test Method & Temp $\left[{ }^{\circ} \mathrm{C}\right]$ & Freq $[\mathrm{Hz}]$ & Requirement \\
\hline Stiffness & & & \\
2PB & 15 & 10 & $>11000 \mathrm{MPa}$ \\
4PB & 20 & 8 & $>7000 \mathrm{MPa}$ \\
ITT & 20 & $124 \mu \mathrm{s}$ & $>7000 \mathrm{MPa}$ \\
Fatigue $\varepsilon_{6}$ & & & \\
2PB & 10 & 25 & $>115$ microstrains \\
4PB & 20 & 30 & $>115$ microstrains \\
\hline
\end{tabular}

Table 3 French Stiffness requirements for selected mixtures (SDA=semi dense asphalt; $\mathrm{AC}=$ asphalt concrete; $\mathrm{B}=$ binder course $\mathrm{EME}=$ high modulus; $\mathrm{T}=$ base course)

\begin{tabular}{|c|c|c|c|c|c|}
\hline \multirow[b]{3}{*}{ Type Swiss } & \multirow[b]{3}{*}{ Type French } & \multicolumn{4}{|c|}{$\begin{array}{c}\text { NFP 98-086:2011 } \\
\text { fundamental approach }\end{array}$} \\
\hline & & \multicolumn{2}{|c|}{ Stiffness [MPa] } & \multicolumn{2}{|c|}{ Fatigue $\varepsilon_{6}$ ( $\mu$ stain) } \\
\hline & & $\min$. & $\begin{array}{l}\max . \\
\text { (z) }\end{array}$ & $\min$. & max. \\
\hline SDA 8-12 & - & - & - & - & - \\
\hline $\mathrm{AC} 8 \mathrm{~S}$ & $\begin{array}{l}\text { EB-BBSG } \\
\text { (classe 1) }\end{array}$ & 5500 & 9000 & 100 & 115 \\
\hline AC 11 & $\begin{array}{l}\text { EB-BBSG } \\
\text { (classe 1) }\end{array}$ & 5500 & 9000 & 100 & 115 \\
\hline AC B $16 \mathrm{H}$ & $\begin{array}{l}\text { EB-BBSG } \\
\text { (classe 2) }\end{array}$ & 7000 & 11000 & 100 & 130 \\
\hline AC B $22 \mathrm{H}$ & $\begin{array}{l}\text { EB-BBSG } \\
\text { (classe 2) }\end{array}$ & 7000 & 11000 & 100 & 130 \\
\hline $\begin{array}{l}\text { AC EME } \\
22 \mathrm{C} 1\end{array}$ & $\begin{array}{l}\text { EB-EME } \\
\text { (classe 1) }\end{array}$ & 14000 & 17000 & 100 & 115 \\
\hline $\begin{array}{l}\text { AC EME } \\
22 \mathrm{C} 2\end{array}$ & $\begin{array}{l}\text { EB-EME } \\
\text { (classe 2) }\end{array}$ & 14000 & 17000 & 130 & 145 \\
\hline $\mathrm{AC} T 22 \mathrm{~S}$ & $\begin{array}{l}\text { EB-BBSG } \\
\text { (classe 1) }\end{array}$ & 5500 & 9000 & 100 & 115 \\
\hline
\end{tabular}


In theory, using performance oriented requirements the expected life of pavements can be improved. Currently in Switzerland, performance based requirements exits for two high modulus mixtures also known as HMAC; AC EME C1 and AC EME C2. The required stiffness modulus is $11000 \mathrm{MPa}$ and $14000 \mathrm{MPa}$ at $15^{\circ} \mathrm{C}$ and $10 \mathrm{~Hz}$ and fatigue resistance $(\varepsilon 6)$ of 100 and 130 micro strains at $10^{\circ} \mathrm{C}$ and $25 \mathrm{~Hz}$ using the two point bending test on trapezoidal specimen, respectively.

The goal of this work is to provide some insight into the stiffness modulus and fatigue behavior using three test methods. As a result, the current work has developed recommendations for testing various asphalt concrete mixtures in Switzerland using the four point bending (4PB-PR) tests on prismatic specimens and indirect tensile tests on cylindrical specimen using two loading conditions (IT-CY and CIT-CY). This paper provides a summary of the project report (Poulikakos, 2019).

\section{Mixture Selection}

Based on current demand at Swiss mixing plants eight mixtures comprising three wearing courses, three binder courses and two base courses were selected as listed in Table 4 . The choice of plant produced mixtures allows a better assessment of the performance of these mixtures in practice as it is well known that there are differences in the plant and laboratory produced mixtures (Rahbar-Rastegar and Daniel 2019). Due to repeated bending, fatigue occurs primarily in the lower layers resulting in bottom up cracking. In this case, the fatigue tests on wearing courses were performed as a general mixture characterization parameter. All mixtures were acquired from three mixing plants as indicated in Table 5 and laboratory compacted without additional aging procedures in addition to warming of mixtures to allow compaction and sample preparation. The mixture properties, including aggregate gradation, binder content void content, binder type as well as other pertinent information are listed in Table 5. 
Test results reported in Table 5 where a result of laboratory tests. It can be seen that the selected mixtures span the range of porous (SDA), intermediate (AC) and dense (AC EME) mixture types. The binder was extracted from the mixtures and penetration and softening point tests were performed and reported in Table 6 . The bitumen extraction procedure is done using chemical solvents; hence, the properties of bitumen after extraction will be somewhat changed (Mikhailenko et al 2020). It is noteworthy to mention that the reclaimed binder from the plant mixtures had often penetrations that were lower or higher than expected with regard to the requirements. For example AC $8 \mathrm{~S}$ had a penetration of 35 when binder 50/70 is required or AC EME C2 had a penetration of 22 when binder 10/20 was required. This discrepancy can be attributed to variability in the RAP supply in case RAP was used, aging during production or quality of virgin binder.

Table 4 Selected mixture types ( $\mathrm{Pmb}=$ polymer modified binder, otherwise straight run binder was used and penetration grade indicated; $\mathrm{SDA}=$ semi dense asphalt; $\mathrm{AC}=$ asphalt concrete; $\mathrm{B}=$ binder course; $\mathrm{EME}=$ high modulus; $\mathrm{T}=$ base course)

\begin{tabular}{lll}
\hline $\begin{array}{l}\text { Mixture } \\
\text { Nr. }\end{array}$ & $\begin{array}{l}\text { Type of Pave- } \\
\text { ment }\end{array}$ & $\begin{array}{l}\text { Mixture Designation, Binder Type } \\
\text { \% RAP }\end{array}$ \\
\hline 1 & Wearing & SDA 8-12, Pmb 45/80-65 \\
& Coarse & AC 8 S, Binder 50/70 \\
2 & & AC11 S, Binder 50/70 \\
3 & Binder Coarse & AC B H, Pmb 25/55-65 \\
4 & & $30 \%$ RAP \\
& & AC B 22 H, Pmb 25/55- 65 \\
5 & & $30 \%$ RAP \\
& & AC EME C1, Binder 15/20 \\
6 & & $30 \%$ RAP \\
7 & AC EME C2, Binder 10/20 \\
8 & & $35 \%$ RAP \\
& & AC T 22 S, Binder 50/70 \\
\hline
\end{tabular}


Table 5 Mixture data

\begin{tabular}{|c|c|c|c|c|c|c|c|c|}
\hline Course Type & Surface & & & Binder & & & Base & \\
\hline Mixture Type & SDA8-12 & AC $8 \mathrm{~S}$ & AC $11 \mathrm{~S}$ & AC B $16 \mathrm{H}$ & AC В 22 H & AC EME C1 & AC EME 22 C2 & AC T $22 \mathrm{~S}$ \\
\hline Mixing Plant & Plant 1 & Plant 1 & Plant 1 & Plant 1 & Plant 1 & Plant 2 & Plant 3 & Plant 1 \\
\hline Binder Type & PmB 45/80-6 & $6.50 / 70$ & $.50 / 70$ & PmB-E 25/55-65 & PmB-E 25/55-65 & $15 / 20$ & $.10 / 20$ & $.50 / 70$ \\
\hline Additive & $0.2 \%$ Fibers & & & $30 \%$ RAP & $30 \%$ RAP & $30 \%$ RAP & $35 \%$ RAP & $50 \%$ RAP \\
\hline Filler & own filler & own filler & own filler & own filler & own filler & & & own filler \\
\hline Aggregate source/ Type & HardC95/10 & HardC70/10 & HardC70/10 & HardC70/10 & HardC70/10 & C90/1 & $C 90 / 1$ & HardC70/10 \\
\hline Binder content [Mass-\%] & 5.8 & 5.8 & 5.4 & 4.9 & 4.5 & 5 & 5.6 & 4.2 \\
\hline Required binder content [Mass-\%] & $\geq 5.8$ & $\geq 5.8$ & $\geq 5.4$ & $\geq 4.4$ & $\geq 4.0$ & $\geq 4.6$ & $\geq 5.2$ & $\geq 4.0$ \\
\hline Max density $[\mathrm{Kg} / \mathrm{m} 3]$ & 2465 & 2476 & 2480 & 2504 & 2535 & 2496 & 2459 & 2538 \\
\hline Bulk density $[\mathrm{Kg} / \mathrm{m} 3]$ & 2146 & 2371 & 2417 & 2371 & 2354 & 2419 & 2404 & 2396 \\
\hline Void Content Marshall [Vol-\%] & 12.9 & 4.2 & 2.6 & 5.3 & 7.1 & 3.1 & 2.2 & 5.6 \\
\hline Required void content Marshall [Vol-\%] & $10 \ldots 14$ & $3 \ldots 6$ & $3 \ldots 6$ & $3 \ldots 6$ & $4 \ldots 7$ & $3 \ldots 6$ & $1 \ldots 4$ & $4 \ldots 7$ \\
\hline Mudule de richesse & 3.8 & 3.9 & 3.5 & 3.3 & 3.1 & 3.3 & & 3 \\
\hline VMA [Vol-\%] & 24.9 & 18.2 & 14.9 & 16.6 & 17.3 & 14.7 & & 14.6 \\
\hline VFB [Vol-\%] & 48.1 & 76.8 & 82.6 & 68.1 & 59 & 79.2 & & 72.6 \\
\hline Aggregate sieve 31.5 [Mass-\%] & 100.0 & 100 & 100.0 & 100.0 & 100.0 & 100.0 & 100.0 & 100.0 \\
\hline Aggregate sieve 22.4 [Mass-\%] & 100.0 & 100 & 100.0 & 100.0 & 99.0 & 100.0 & 100.0 & 96.0 \\
\hline Aggregate sieve 22.4 [Mass-\%]Tolerance & & & & & &.$-9 /+5$ &.$-9 /+5$ & \\
\hline Aggregate sieve 16.0 [Mass-\%] & 100.0 & 100 & 100.0 & 99.0 & 92.0 & 85.0 & 87.0 & 84.0 \\
\hline Aggregate sieve 16.0 [Mass-\%]Tolerance & & & &.$-9 /+5$ &.$-9 /+5$ & & &.$-9 /+5$ \\
\hline Aggregate sieve 11.2 [Mass-\%] & 100.0 & 100 & 100.0 & 90.0 & 81.0 & 72.0 & 76.0 & 72.0 \\
\hline Aggregate sieve 11.2 [Mass-\%]Tolerance & & & & & \pm 9 & \pm 9 & \pm 9 & \pm 9 \\
\hline Aggregate sieve 8.0 [Mass-\%] & 99.0 & 99 & 88.0 & 80.0 & 76.0 & 58.0 & 67.0 & 64.0 \\
\hline Aggregate sieve 8.0 [Mass-\%]Tolerance &.$-8 /+5$ &.$-8 /+5$ &.$-8 /+5$ & \pm 9 & & & & \\
\hline Aggregate sieve 5.6 [Mass-\%] & 66.0 & 87 & 75.0 & 63.0 & 62.0 & 49.0 & 52.0 & 51.0 \\
\hline Aggregate sieve 4.0 [Mass-\%] & 35.0 & 75 & 60.0 & 50.0 & 49.0 & 42.0 & 40.0 & 42.0 \\
\hline Aggregate sieve 4.0 [Mass-\%]Tolerance & \pm 7 & \pm 7 & \pm 7 & & & & & \\
\hline Aggregate sieve 2.0 [Mass-\%] & 22.0 & 46.7 & 38.0 & 33.0 & 32.0 & 29.0 & 28.0 & 30.0 \\
\hline Aggregate sieve 2.0 [Mass-\%]Tolerance & \pm 6 & \pm 6 & \pm 6 & \pm 7 & \pm 7 & \pm 7 & \pm 7 & \pm 7 \\
\hline Aggregate sieve 1.0 [Mass-\%] & 17.0 & 30.7 & 25.7 & 22.0 & 21.5 & 21.0 & 20.8 & 21.0 \\
\hline Aggregate sieve 1.0 [Mass-\%]Tolerance & \pm 1 & \pm 1 & \pm 1 & \pm 5 & \pm 5 & \pm 5 & \pm 5 & \pm 5 \\
\hline Aggregate sieve 0.5 [Mass-\%] & 14.0 & 23.5 & 19.2 & 17.0 & 16.3 & 16.0 & 17.0 & 16.0 \\
\hline Aggregate sieve 0.25 [Mass-\%] & 12.0 & 18.9 & 14.2 & 13.3 & 12.3 & 12.0 & 13.9 & 12.0 \\
\hline Aggregate sieve 0.125 [Mass-\%] & 10.0 & 13.4 & 9.8 & 8.7 & 8.5 & 9.0 & 9.3 & 8.0 \\
\hline Aggregate sieve 0.063 [Mass-\%] & 7.8 & 7.9 & 6.1 & 5.7 & 5.2 & 6.4 & 9.3 & 5.1 \\
\hline Aggregate sieve 0.063 [Mass-\%]Tolerance & \pm 2 & \pm 2 & \pm 2 & \pm 3 & \pm 3 & \pm 3 & \pm 3 & \pm 3 \\
\hline Marshall Stability [KN] & 11.1 & 12.4 & 12.0 & 18.2 & 17.2 & 23.6 & 19.6 & 13.0 \\
\hline Marshall Flow [mm] & 3.1 & 2.8 & 3.6 & 2.8 & 3.0 & 3.9 & 4.3 & 2.6 \\
\hline Marshall Ratio $[\mathrm{KN} / \mathrm{mm}]$ & 3.7 & 4.42 & 3.3 & 6.5 & 5.7 & 6.1 & 4.6 & 5.0 \\
\hline
\end{tabular}

Notes on Table 5:

$A C 11 S$ did not satisfy the void content of $3 \ldots 6$ as marked in red in the table

$A C 8 S, A C 11 \mathrm{~S}, A C B 16 \mathrm{H}, A C B 22 \mathrm{H}$ did not fulfill the aggregate gradation requirements as marked in red in the table. Module de riches= richness modulus an indication of binder film thickness

Table 6 Recovered binder properties for all mixtures

\begin{tabular}{lcccc}
\hline Mixture & $\begin{array}{l}\text { Binder Content } \\
{[\mathrm{M} \%]}\end{array}$ & Penetration $[\mathrm{dmm}]$ & Softening Point $\left[{ }^{\circ} \mathrm{C}\right]$ & $\begin{array}{l}\text { Req'd Binder } \\
\text { type }\end{array}$ \\
\hline SDA 8-12 & 5.8 & 45 & 60.2 & PmB-E 45/80-65 \\
AC 8 S & 5.8 & 35 & 55.2 & $50 / 70$ \\
AC 11 S & 5.4 & 34 & 60.4 & $50 / 70$ \\
AC B 16 H & 4.9 & 16 & 77.2 & PmB-E 25/55-65 \\
AC B 22 H & 4.6 & 34 & 58.8 & PmB-E 25/55-65 \\
AC EME C1 & 5.0 & 16 & 75.6 & PmB-E 10/40-70 \\
AC EME C2 & 5.4 & 22 & 65.0 & $10 / 20$ \\
AC T 22 S & 4.2 & 26 & 67.8 & PmB-E 25/55-65 \\
\hline
\end{tabular}




\section{Experimental Methods}

\section{Test Parameters}

The eight mixtures identified in section 2 were tested using three types of stiffness and fatigue tests as listed in Table 7. Those were Indirect Tensile Test on Cylindrical specimen (IT-CY), Cyclic Indirect Tension on Cylindrical specimens (CIT-CY) and Four Point Bending test on Prismatic specimens (4PB-PR). The testing parameters were chosen based on those defined for type testing (EN 13108-20:2016) and listed in Table 7. Two mixtures (AC 8 S and AC B $22 \mathrm{H}$ ) were tested additionally with three temperatures and several frequencies. One mixture (AC 8 S) was tested using the 4PB-PR test in two labs Empa, Switzerland and Technical University of Vienna (TUV) in Austria, to compare impacts of different test machines. As fatigue criteria the conventional criteria as defined by the standard,namely, failure number of load applications when the complex stiffness modulus has decreased to half its initial value was used. . Table 9 gives an estimated time to perform these tests that depend on required frequency and rest time. The time needed should help in the selection process. For this project a total of 303 samples were prepared and tested.

Table 7 Chosen parameters for type testing for modulus and fatigue tests (EN 13108-20:2016)

Modu- Fatigue

lus

\begin{tabular}{lllll}
$\begin{array}{l}\text { Type of load- } \\
\text { ing }\end{array}$ & Temp & $\begin{array}{l}\text { Freq/Loading } \\
\text { time }\end{array}$ & $\begin{array}{l}\text { Tempera- } \\
\text { ture }\end{array}$ & $\begin{array}{l}\text { Freq/loading } \\
\text { time }\end{array}$ \\
\hline 4PB.PR & $20^{\circ} \mathrm{C}$ & $8 \mathrm{~Hz}$ & $20^{\circ} \mathrm{C}$ & $10 \mathrm{~Hz}$ \\
IT-CY & $20^{\circ} \mathrm{C}$ & 124 milliseconds & $20^{\circ} \mathrm{C}$ & \\
CIT-CY & $10^{\circ} \mathrm{C}$ & $10 \mathrm{~Hz}$ & $10^{\circ} \mathrm{C}$ & $10 \mathrm{~Hz}$ \\
\hline
\end{tabular}


Table 8 Experimental Program

\begin{tabular}{|c|c|c|c|c|}
\hline Type of Test & 4PB-PR & IT-CY & CIT-CY & Notes \\
\hline $\begin{array}{l}\text { Number of } \\
\text { Mixtures }\end{array}$ & 8 & 8 & 8 & $\begin{array}{l}3 \text { Wearing } \\
\text { courses } \\
3 \text { Binder courses } \\
2 \text { Base courses }\end{array}$ \\
\hline $\begin{array}{l}\text { Test Condi- } \\
\text { tions, Stiffness } \\
\text { (Temp/Freq) }\end{array}$ & $20^{\circ} \mathrm{C} / 8 \mathrm{~Hz}$ & $20^{\circ} \mathrm{C}$ & $10^{\circ} \mathrm{C} / 10 \mathrm{~Hz}$ & 4 Replicates \\
\hline $\begin{array}{l}\text { Additional } \\
\text { Test Condi- } \\
\text { tions, Stiffness } \\
\text { (Temp/Freq) }\end{array}$ & $\begin{array}{l}10,15,20^{\circ} \mathrm{C} \\
0.1,1,3,8, \\
15,20 \mathrm{~Hz}(\mathrm{AC} \\
8) \\
3,10,15 \mathrm{~Hz} \\
(\mathrm{AC} \mathrm{B} 22)\end{array}$ & $10,15,20^{\circ} \mathrm{C}$ & $\begin{array}{l}10,15 \\
20^{\circ} \mathrm{C} \\
3,10,15 \\
\mathrm{~Hz}\end{array}$ & $\begin{array}{l}\text { For AC } 8 \text { S } \\
\& \text { AC B } 22 \mathrm{H}\end{array}$ \\
\hline $\begin{array}{l}\text { Test Condi- } \\
\text { tions, Fatigue } \\
\text { (Temp/Freq) }\end{array}$ & $20^{\circ} \mathrm{C} / 10 \mathrm{~Hz}$ & $20^{\circ} \mathrm{C}$ & $10^{\circ} \mathrm{C} / 10 \mathrm{~Hz}$ & $\begin{array}{l}\text { IT-CY/CIT-CY: } \\
9 \text { Replicates } \\
\text { 4PB-TR: } \\
\text { 18 Replicates }\end{array}$ \\
\hline
\end{tabular}

Table 9 Estimated time for each tests

\begin{tabular}{llccc}
\hline & & $\begin{array}{c}\text { Temp. condi- } \\
\text { tioning [h] }\end{array}$ & Tests [h] & Total [d] \\
\hline 4PB-PR & Modulus & 2 & 2 & \\
& Fatigue & & & \\
& $(18$ samples) & 2 & 517 & 22 \\
CIT-CY & Modulus & 2 & 2 & \\
& Fatigue & 2 & 93 & 4 \\
& (9 samples) & & & \\
IT-CY & Modulus & 2 & 2 & 19 \\
& Fatigue & 2 & 463 & \\
& (9 samples) & & & \\
\hline
\end{tabular}

\section{Specimen Preparation}

The standards (EN 12697-26 and -24) specify that the specimens for 4PB-PR and IT-CY, CIT-CY should be produced by coring/sawing from slabs made in laboratory or taken from road layers. For cylindrical specimen suitable laboratory moulds are also allowed. In this work only slabs have been used in order to use a uniform compaction method for all samples. The mixtures were collected from the asphalt mixing plant in $800 \mathrm{~kg}$ batches that were stored in carton boxes of $25 \mathrm{~kg}$ each that were stored in a dark basement with constant temperature 
and humidity minimizing aging. Before compaction the cartons were warmup in a microwave oven for a few minutes. All samples were compacted using the French Roller Compactor (EN 12697-22) using a steel roller. The steel roller was used instead of the conventional pneumatic tire as own experience showed that more homogeneous specimens can be obtained using this method. $500 \mathrm{mmx} 180 \mathrm{mmx} 10 \mathrm{~mm}$ slab were compacted to the Marshall specimen target density. $100 \mathrm{~mm}$ and $150 \mathrm{~mm}$ diameter cylindrical samples were cored vertically and cut to yield eight samples for maximum aggregate size $\mathrm{D} \leq 16 \mathrm{~mm}$ and three samples for $\mathrm{D}>16 \mathrm{~mm}$. The prismatic specimen were cut from the middle of the slab allowing $15 \mathrm{~mm}$ cover on top and $25 \mathrm{~mm}$ cover on the bottom of the slab. Final size of the samples was $60 \mathrm{mmx} 60 \mathrm{mmx} 500 \mathrm{~mm}$.

\section{Experimental results}

\section{Comparison of stiffness modulus results}

The 4PB-PR test on one mixture AC $8 \mathrm{~S}$ was performed at two labs (Empa and TUV). These specimens were compacted and cut at Empa and delivered to TUV for testing. Both labs use the same machine with Empa using a newer clamp system for holding the specimen.

The results for stiffness modulus for mixture AC $8 \mathrm{~S}$ are shown in Figure 1 and those for phase angle in Figure 2. With some exceptions, the results from Empa that was repeated twice are generally slightly higher than TUV and the phase angles slightly lower. The difference is larger at $20^{\circ} \mathrm{C} .20^{\circ} \mathrm{C}, 8 \mathrm{~Hz}$ are the test parameters for the type testing as defined in Table 7 . At this temperature and frequency the difference was $11.6 \%$ for Modulus and 2.9\% for Phase angle. The phase shift angle must decrease with increasing frequency indicating that $10{ }^{\circ} \mathrm{C} /$ $20 \mathrm{~Hz}$ we are outside the measuring capabilities of the equipment at both labs. The difference in the results can be attributed mostly to the difference in voids content for TUV, Empa1 and Empa2 being 2.4, 2.3 and 5\%-vol.\% respectively. Impacts of air voids on mechanical parameters have been investigates in earlier studies (Hofko, Blab et al. 2012, Steiner, Hofko et al. 


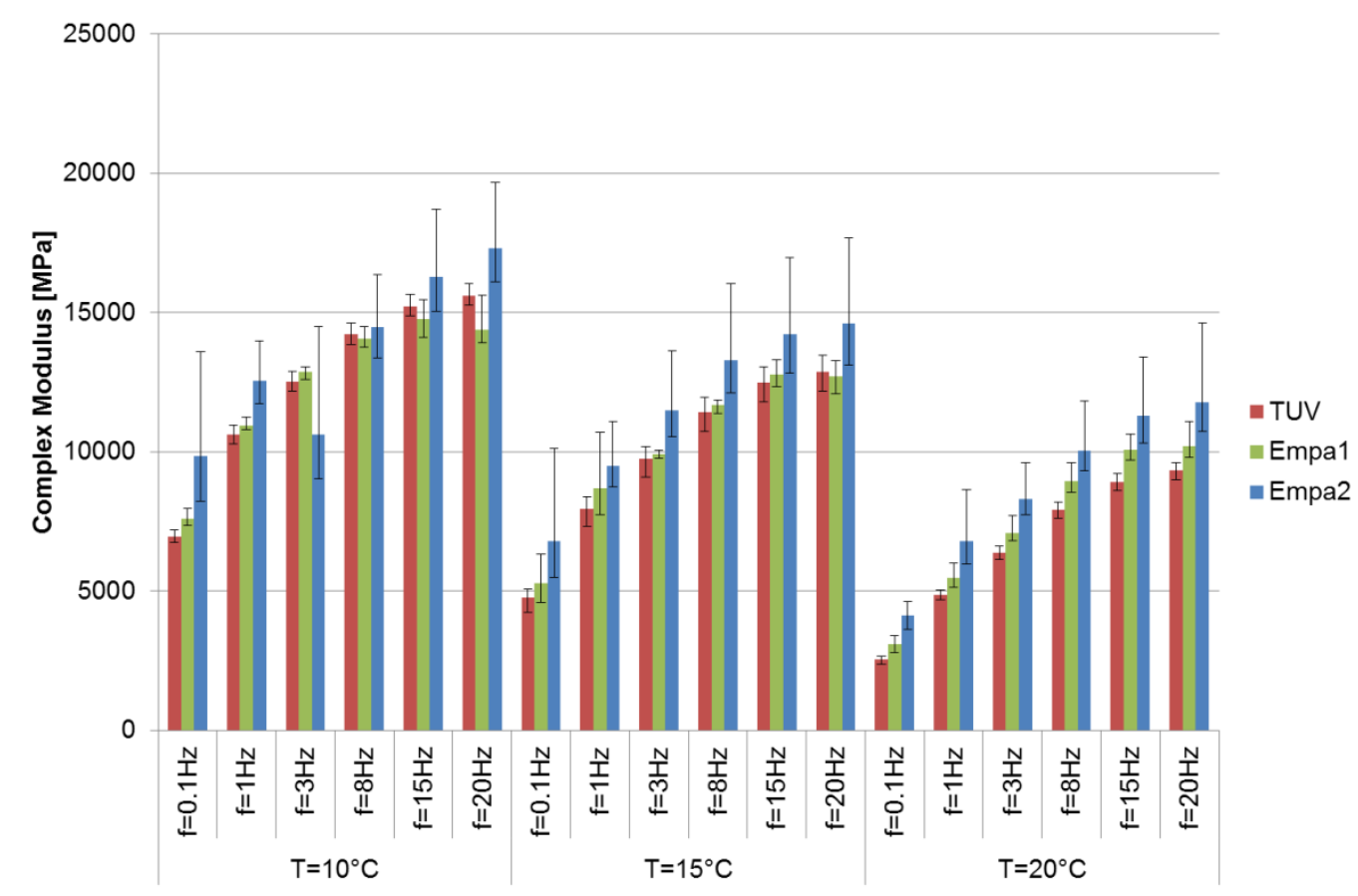

Figure 1 Comparison of stiffness modulus values between Empa and TUV at three temperatures and six frequencies using the 4PB-PR test method; error bars show maximum and minimum values of four samples

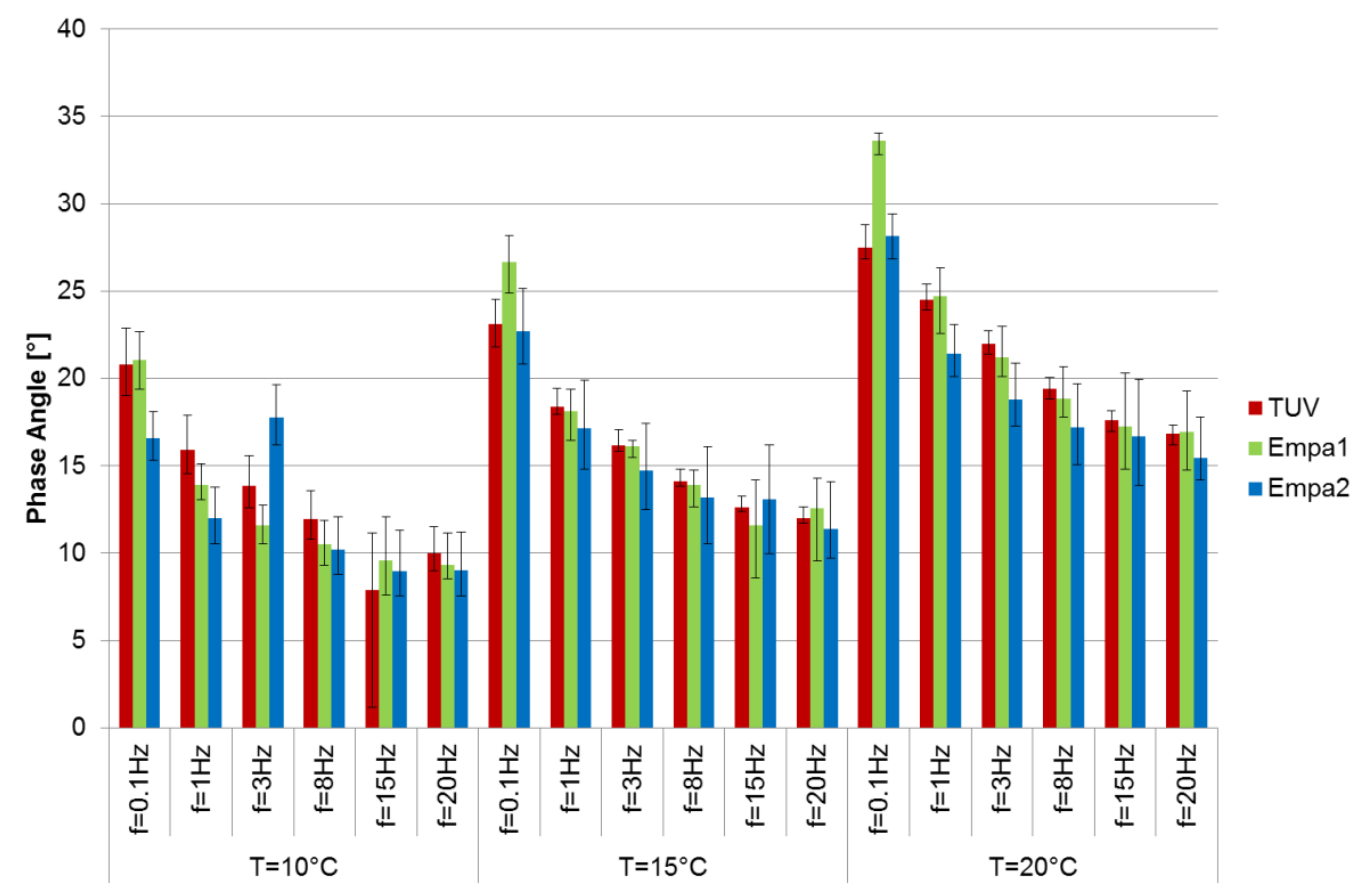

Figure 2 Comparison of phase angle values between Empa and TUV at three temperatures and six frequencies using the 4PB-PR test method; error bars show maximum and minimum values of four samples 
Referring to the RILEM comparative study discussed earlier, and shown in Table 1; it can be seen that the difference is temperature and frequency dependent and a maximum of $10 \%$ and $18 \%$ in modulus and in phase angle was reported respectively. The results presented above are similar to these reported values.

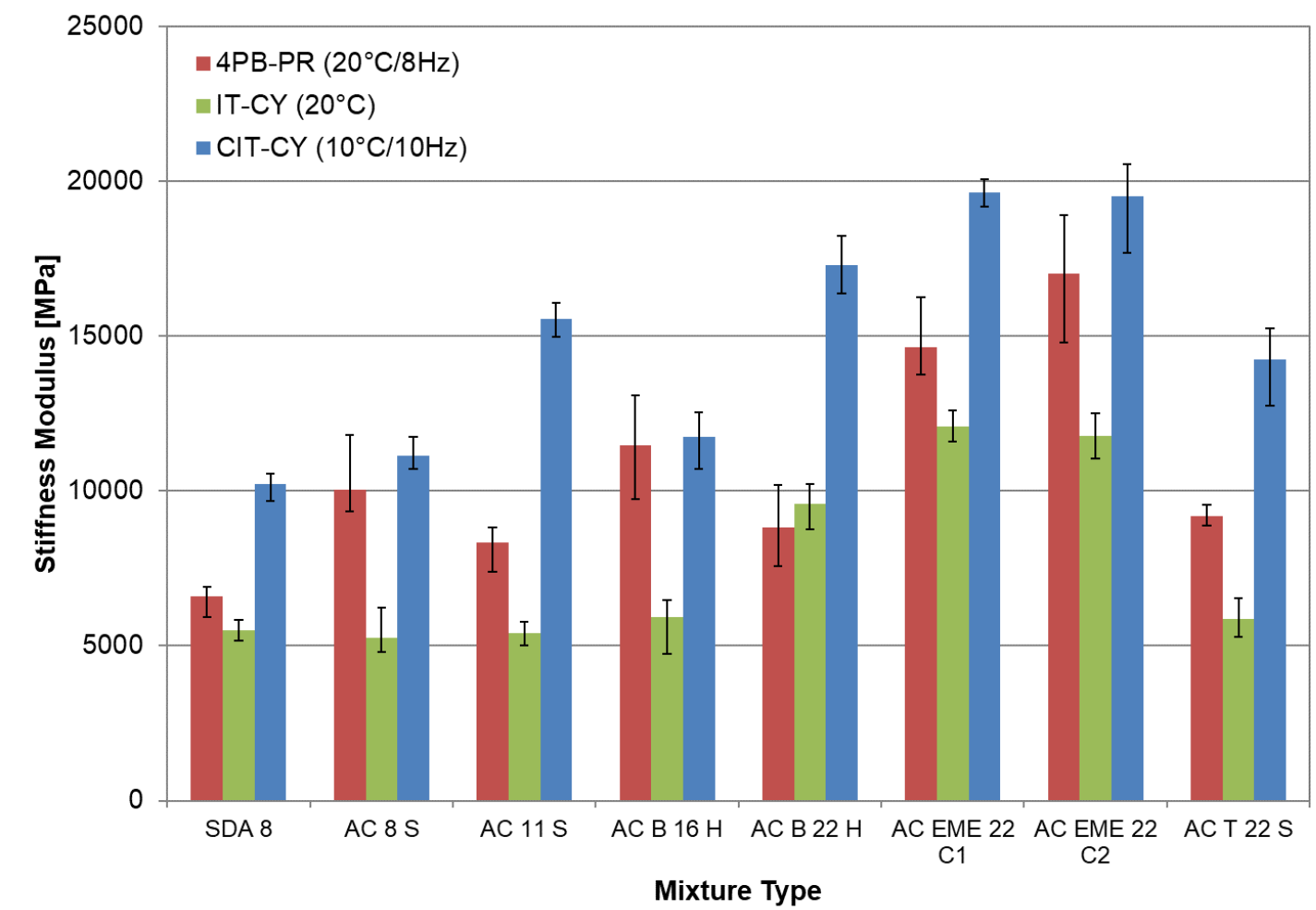

Figure 3 Stiffness modulus for all mixtures obtained with 4PB-PR , IT-CY and CIT-CY methods, error bars indicate maximum and minimum values

The results of stiffness modulus obtained by the 4PB-PR, IT-CY and CIT-CY are listed in

Table 10 and shown in Figure 3. As the $4 \mathrm{~PB}-\mathrm{PR}$ results are at $20^{\circ} \mathrm{C}, 8 \mathrm{~Hz}$, and CIT$\mathrm{CY}$ at $10^{\circ} \mathrm{C}, 10 \mathrm{~Hz}$ it is expected that the modulus values for CIT-CY would be higher than that obtained with 4PB-PR. As shown in this figure the trend is similar for both tests.

Input from practitioners has indicated that AC B $16 \mathrm{H}$ and $\mathrm{AC} B 22 \mathrm{H}$ would have similar results. However, all test methods show this not to be the case. 
IT-CY tests performed on eight mixtures did not show sensitivity to the mixture type as much as the other tests 4PB-PR and CIT-CY that use a sinusoidal continuous force application. The results of IT-CY also did not follow the same trend as the 4PB-PR and CIT-CY.

This could be attributed to the pulse form of the applied load with a resting period that allows the material to recover between applied loads.

Table 10 Modulus results for all mixtures and test types

\begin{tabular}{|c|c|c|c|c|c|c|}
\hline Mixture & & $\begin{array}{c}\text { Modulus } \\
\mathrm{G}^{*} \text { mean } \\
{[\mathrm{MPa}]}\end{array}$ & $\begin{array}{l}\text { max- } \\
\text { mean }\end{array}$ & $\begin{array}{c}\text { mean- } \\
\text { min }\end{array}$ & $\begin{array}{r}\text { avg VC } \\
\text { [vol\%] }\end{array}$ & $\begin{array}{l}\text { reqd } \\
\text { VC }\end{array}$ \\
\hline & & & & & & $10 \ldots 1$ \\
\hline \multirow[t]{4}{*}{ SDA 8-12 } & $4 \mathrm{~PB}(20 \mathrm{C} / 8 \mathrm{~Hz})$ & 6599 & 300 & 678 & 11.7 & 4 \\
\hline & IT-CY $\left(20^{\circ} \mathrm{C}\right)$ & 5496 & 334 & 327 & 11.5 & \\
\hline & CIT-CY & & & & & \\
\hline & $\left(10^{\circ} \mathrm{C} / 10 \mathrm{~Hz}\right)$ & 10231 & 311 & 562 & 11.5 & \\
\hline \multirow[t]{4}{*}{$\mathrm{AC} 8 \mathrm{~S}$} & $4 \mathrm{~PB}(20 \mathrm{C} / 8 \mathrm{~Hz})$ & 10042 & 1771 & 712 & 5.0 & $3 \ldots 6$ \\
\hline & IT-CY $\left(20^{\circ} \mathrm{C}\right)$ & 5263 & 980 & 476 & 5.0 & \\
\hline & CIT-CY & & & & & \\
\hline & $\left(10^{\circ} \mathrm{C} / 10 \mathrm{~Hz}\right)$ & 11126 & 602 & 431 & 5 & \\
\hline \multirow[t]{4}{*}{ AC11 S } & $4 \mathrm{~PB}(20 \mathrm{C} / 8 \mathrm{~Hz})$ & 8321 & 494 & 919 & 3.1 & $3 \ldots 6$ \\
\hline & IT-CY $\left(20^{\circ} \mathrm{C}\right)$ & 5406 & 353 & 408 & 4.1 & \\
\hline & CIT-CY & & & & & \\
\hline & $\left(10^{\circ} \mathrm{C} / 10 \mathrm{~Hz}\right)$ & 15552 & 511 & 570 & 4.1 & \\
\hline \multirow[t]{4}{*}{ AC B $16 \mathrm{H}$} & $4 \mathrm{~PB}(20 \mathrm{C} / 8 \mathrm{~Hz})$ & 11469 & 1610 & 1727 & 4 & $3 \ldots 6$ \\
\hline & IT-CY $\left(20^{\circ} \mathrm{C}\right)$ & 5925 & 536 & 1199 & 4.5 & \\
\hline & CIT-CY & & & & & \\
\hline & $\left(10^{\circ} \mathrm{C} / 10 \mathrm{~Hz}\right)$ & 11737 & 783 & 1034 & 4.5 & \\
\hline \multirow[t]{4}{*}{ AC B $22 \mathrm{H}$} & $4 \mathrm{~PB}(20 \mathrm{C} / 8 \mathrm{~Hz})$ & 8813 & 1387 & 1243 & 5.1 & $4 \ldots 7$ \\
\hline & IT-CY $\left(20^{\circ} \mathrm{C}\right)$ & 9576 & 636 & 820 & 4.1 & \\
\hline & CIT-CY & & & & & \\
\hline & $\left(10^{\circ} \mathrm{C} / 10 \mathrm{~Hz}\right)$ & 17291 & 938 & 919 & 4.1 & \\
\hline \multicolumn{7}{|l|}{ AC EME 22} \\
\hline \multirow[t]{4}{*}{$\mathrm{C} 1$} & $4 \mathrm{~PB}(20 \mathrm{C} / 8 \mathrm{~Hz})$ & 14636 & 1617 & 893 & 2.1 & $3 \ldots 6$ \\
\hline & IT-CY $\left(20^{\circ} \mathrm{C}\right)$ & 12070 & 521 & 474 & 3.6 & \\
\hline & CIT-CY & & & & & \\
\hline & $\left(10^{\circ} \mathrm{C} / 10 \mathrm{~Hz}\right)$ & 19638 & 428 & 473 & 3.6 & \\
\hline \multicolumn{7}{|l|}{ AC EME 22} \\
\hline \multirow[t]{4}{*}{$\mathrm{C} 2$} & $4 \mathrm{~PB}(20 \mathrm{C} / 8 \mathrm{~Hz})$ & 17007 & 1890 & 2234 & 1.0 & $1 \ldots 4$ \\
\hline & IT-CY $\left(20^{\circ} \mathrm{C}\right)$ & 11772 & 721 & 740 & 1.4 & \\
\hline & CIT-CY & & & & & \\
\hline & $\left(10^{\circ} \mathrm{C} / 10 \mathrm{~Hz}\right)$ & 19507 & 1036 & 1836 & 1.4 & \\
\hline \multirow[t]{4}{*}{ AC T $22 \mathrm{~S}$} & $4 \mathrm{~PB}(20 \mathrm{C} / 8 \mathrm{~Hz})$ & 9197 & 355 & 326 & 4.1 & $4 \ldots 7$ \\
\hline & IT-CY $\left(20^{\circ} \mathrm{C}\right)$ & 5864 & 671 & 567 & 5.6 & \\
\hline & $\begin{array}{l}\text { CIT-CY } \\
\left(10^{\circ} \mathrm{C} / 10 \mathrm{~Hz}\right)\end{array}$ & & & 1470 & 56 & \\
\hline & $\left(10^{\circ} \mathrm{C} / 10 \mathrm{~Hz}\right)$ & 14231 & 1023 & 1470 & 5.6 & \\
\hline
\end{tabular}




\section{Comparison of fatigue results per mixture type}

Table 11 summarizes the 4PB-PR results for all the tested mixtures. For each test that was carried out at $20^{\circ} \mathrm{C}$ and $10 \mathrm{~Hz}$ frequency at least 18 samples were used. The parameter $1 / b$ is the slope of the fatigue line. The higher the slope the more sensitive the mixture is to fatigue loading and early failure. In this regard, using prismatic samples, AC B $16 \mathrm{H}$ and AC EME C1 were the most fatigue resistant, whereas AC B $22 \mathrm{H}$ and AC T $22 \mathrm{~S}$ were the least.

. The 4PB-PR test results shown in Table 11 and Figure 4 indicate similar fatigue resistance with $\varepsilon 6 \sim 180-200 \mu \mathrm{m} / \mathrm{m}$ for SDA 8-12 and AC 8 S, AC 11 S, AC EME C1 and AC EME C2 mixtures. Whereas AC B $22 \mathrm{H}$ and AC T $22 \mathrm{~S}$ had the lowest fatigue resistance with $\varepsilon 6=169$ and $134 \mu \mathrm{m} / \mathrm{m}$ respectively. The AC mixtures with Nominal maximum aggregate size $(\mathrm{NMAS})=22 \mathrm{~mm}$ had the lowest fatigue resistance. Whereas the AC EME mixtures with NMAS=22mm performed similar to AC mixtures of lower NMAS.

e It is seen from CIT-CY fatigue resistance results in Table 12 and Figure 4 that since this is not a bending test the results are not consistent with those of the bending test discussed above and therefore are not ideal for evaluations of fatigue resistance of mixtures.

The values for fatigue resistance using 4PB-PR tests lie in the range of $200 \mu \mathrm{m} / \mathrm{m}$ whereas for the CIT-CY in the range of $50 \mu \mathrm{m} / \mathrm{m}$.

The fatigue test for IT-CY were part of the original experimental plan. As mentioned in Table 9, these fatigue tests proved to be very time intensive and were abandoned and therefore not performed in this study. 
Table 11 Fatigue results for Four Point Bending with prismatic samples $4 \mathrm{~PB}-\mathrm{PR}\left(20^{\circ} \mathrm{C} / 10 \mathrm{~Hz}\right)$

\begin{tabular}{|c|c|c|c|c|c|c|c|c|}
\hline Mixture & $\begin{array}{c}\varepsilon 6 \\
{[\mu \mathrm{m} /} \\
\mathrm{m}]\end{array}$ & Fatigue eqn & $\begin{array}{l}\mathbf{R}^{2} \\
{[-]}\end{array}$ & $\mathbf{a}$ & $-1 / \mathrm{b}$ & $\begin{array}{l}\operatorname{avg~VC} \\
\text { [vol-\%] }\end{array}$ & $\begin{array}{l}\text { req'd VC } \\
\text { [vol-\%] }\end{array}$ & $\begin{array}{l}\text { Marshall VC } \\
\text { [vol-\%] }\end{array}$ \\
\hline SDA 8-12 & 187 & $\begin{array}{l}y=- \\
4.2956 x+15.759 \\
y=-\end{array}$ & 0.76 & $\begin{array}{l}15.76 \\
17.80\end{array}$ & 4.30 & 11.7 & $10 . .14$ & 12.9 \\
\hline $\mathrm{AC} 8 \mathrm{~S}$ & 182 & $\begin{array}{l}5.2212 \mathrm{x}+17.801 \\
\mathrm{y}=-3.2931 \mathrm{x}\end{array}$ & 0.73 & 1 & 5.22 & 5.1 & $3 \ldots 6$ & 3.1 \\
\hline AC $11 \mathrm{~S}$ & 184 & $\begin{array}{l}+13.462 \\
y=- \\
7.2996 x+22.89\end{array}$ & 0.74 & 13.46 & 3.29 & 3.1 & $3 \ldots 6$ & 2.6 \\
\hline AC B $16 \mathrm{H}$ & 206 & $\begin{array}{l}9 \\
y=- \\
5.7449 x+18.80\end{array}$ & 0.76 & 22.90 & 7.30 & 3.9 & $3 \ldots 6$ & 5.3 \\
\hline $\begin{array}{l}\text { AC B } 22 \mathrm{H} \\
\text { AC EME }\end{array}$ & 169 & $\begin{array}{l}6 \\
y=-\end{array}$ & 0.79 & 18.81 & 5.74 & 5.1 & $4 \ldots 7$ & 6.4 \\
\hline $\mathrm{C} 1$ & 197 & $6.766 x+21.531$ & 0.91 & 21.53 & 6.77 & 2.11 & $3 \ldots 6$ & 3.1 \\
\hline $\begin{array}{l}\text { AC EME } \\
\text { C2 }\end{array}$ & 182 & $\begin{array}{c}y=- \\
5.0384 x+17.39 \\
y=-\end{array}$ & 0.89 & $\begin{array}{l}17.39 \\
17.23\end{array}$ & 5.04 & 1 & $1 \ldots 4$ & 2.2 \\
\hline AC T $22 \mathrm{~S}$ & 134 & $5.2793 x+17.231$ & 0.59 & 1 & 5.28 & 4.07 & $4 \ldots 7$ & 5.6 \\
\hline
\end{tabular}

Table 12 Fatigue results for cyclic indirect tensile test with cylindrical samples CIT-CY $\left(10^{\circ} \mathrm{C} / 10 \mathrm{~Hz}\right)$

\begin{tabular}{|c|c|c|c|c|c|c|c|c|}
\hline Mixture & $\begin{array}{c}86 \\
{[\mu \mathrm{m} / \mathbf{m}]}\end{array}$ & Fatigue eqn & $\mathbf{R}^{2}[-]$ & $\mathbf{a}$ & $-1 / b$ & $\begin{array}{l}\text { avg VC [vol- } \\
\%]\end{array}$ & $\begin{array}{l}\text { req'd VC } \\
\text { [vol-\%] }\end{array}$ & $\begin{array}{l}\text { Marshall } \\
\text { VC } \\
\text { [vol-\%] }\end{array}$ \\
\hline SDA 8-12 & 33 & $y=-2.4785 x+9.7521$ & 0.72 & 9.75 & 2.48 & 11.7 & $10 . .14$ & 12.9 \\
\hline AC $8 \mathrm{~S}$ & 66 & $y=-3.9064+13.108$ & 0.97 & 13.10 & 3.90 & 4.9 & $3 \ldots 6$ & 3.1 \\
\hline $\mathrm{AC} 11 \mathrm{~S}$ & 59 & $\begin{array}{l}y=-2.6553 x+10.699 \\
y=2.8875 x+11.0\end{array}$ & 0.81 & 10.70 & 2.66 & 4 & $3 \ldots 6$ & 2.6 \\
\hline AC B $16 \mathrm{H}$ & 56 & 2 & 0.90 & 11.05 & 2.89 & 4.7 & $3 \ldots 6$ & 5.3 \\
\hline $\begin{array}{l}\text { AC B } 22 \mathrm{H} \\
\text { AC EME }\end{array}$ & 48 & $y=-2.9314 x+10.919$ & 0.67 & 10.92 & 2.93 & 5.2 & $4 \ldots 7$ & 6.4 \\
\hline $\begin{array}{l}\text { C1 } \\
\text { AC EME }\end{array}$ & 58 & $y=-4.5891 x+14.109$ & 0.85 & 14.11 & 4.59 & 3.5 & $3 \ldots 6$ & 3.1 \\
\hline $\mathrm{C} 2$ & 69 & $y=-3.638 x+12.68$ & 0.57 & $\begin{array}{l}12.68 \\
12.02\end{array}$ & 3.64 & 1.38 & $1 \ldots 4$ & 2.2 \\
\hline $\mathrm{AC} T 22 \mathrm{~S}$ & 88 & $y=-3.0973 x+12.022$ & 0.91 & 2 & 3.10 & 5.6 & $4 \ldots 7$ & 5.6 \\
\hline
\end{tabular}




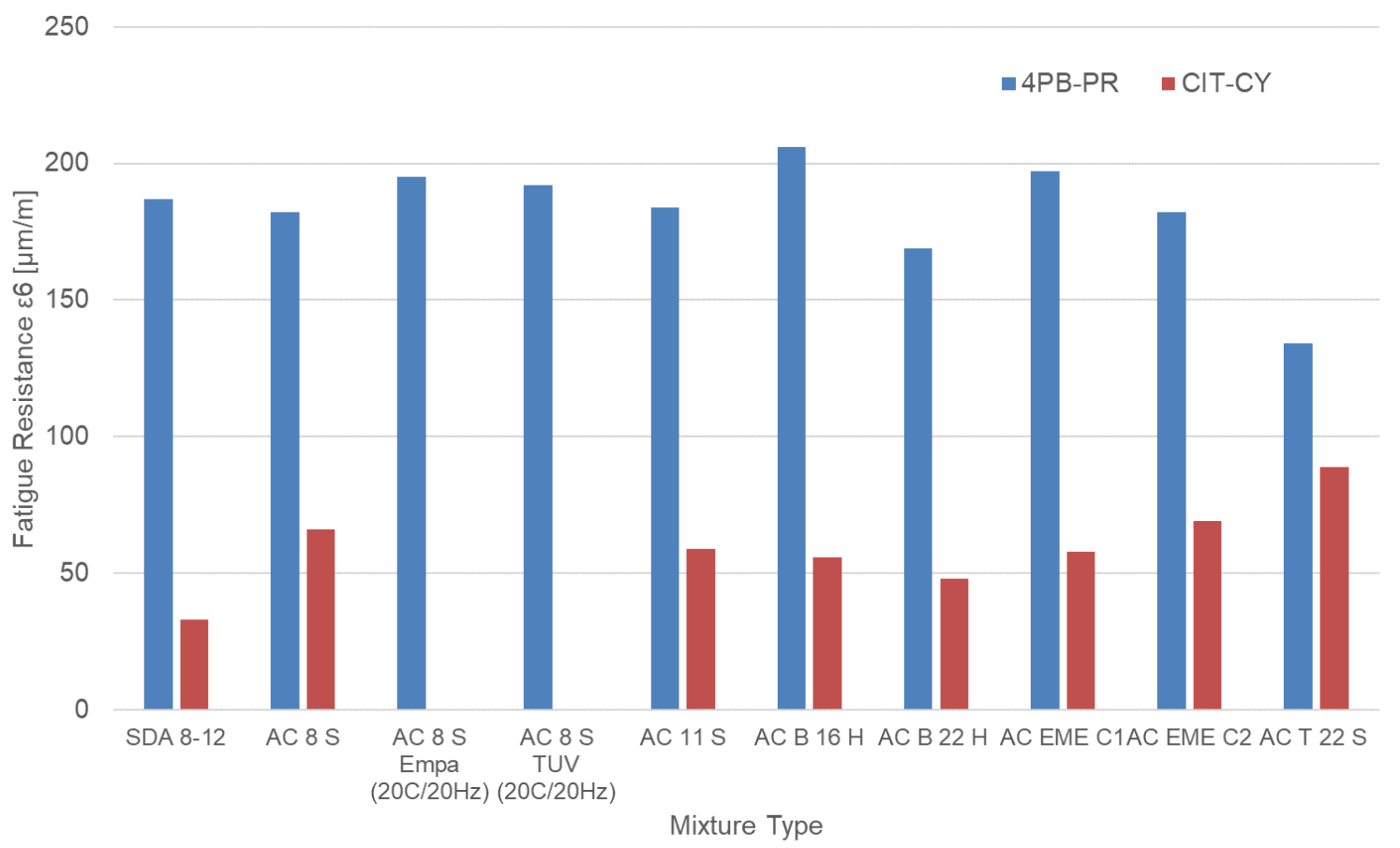

Figure 4 Fatigue resistance of all mixtures using the 4PB-PR tests at $20 \mathrm{C} / 10 \mathrm{~Hz}$ (also $20 \mathrm{C} / 20 \mathrm{~Hz}$ for $\mathrm{AC} 8 \mathrm{~S}$ ) and CIT-CY at $10^{\circ} \mathrm{C} / 10 \mathrm{~Hz}$

Figure 5 shows the goodness of the fatigue curve R 2 for different mixture types using both 4PB-PR and CIT-CY tests and in Figure 6 those values for the different tests are shown. The average $\mathrm{R} 2$ value for $4 \mathrm{~PB}-\mathrm{PR}$ tests is 0.83 and for CIT-CY is 0.85 showing that the test types do not affect the goodness of the fatigue curves on average. Furthermore, no systematic dependence of R2 on mixture type or test type was seen. An R2=0.75 is recommended for standardization in order to have a good set of data. This value was reached by all mixtures and test types except AC EME C2 with CIT-CY with R2=0.5697. In order to reach a high R2 more samples and more homogeneous samples are needed and in most cases, more than the minimum number of samples would have to be tested. The mixture with a low R2 values were investigated further. These were often caused by single outliers. However, the raw data did not give an indication that these outliers had different properties than the rest of the samples; for example in terms of void content. The outliers could be due to local defects in the sample. 


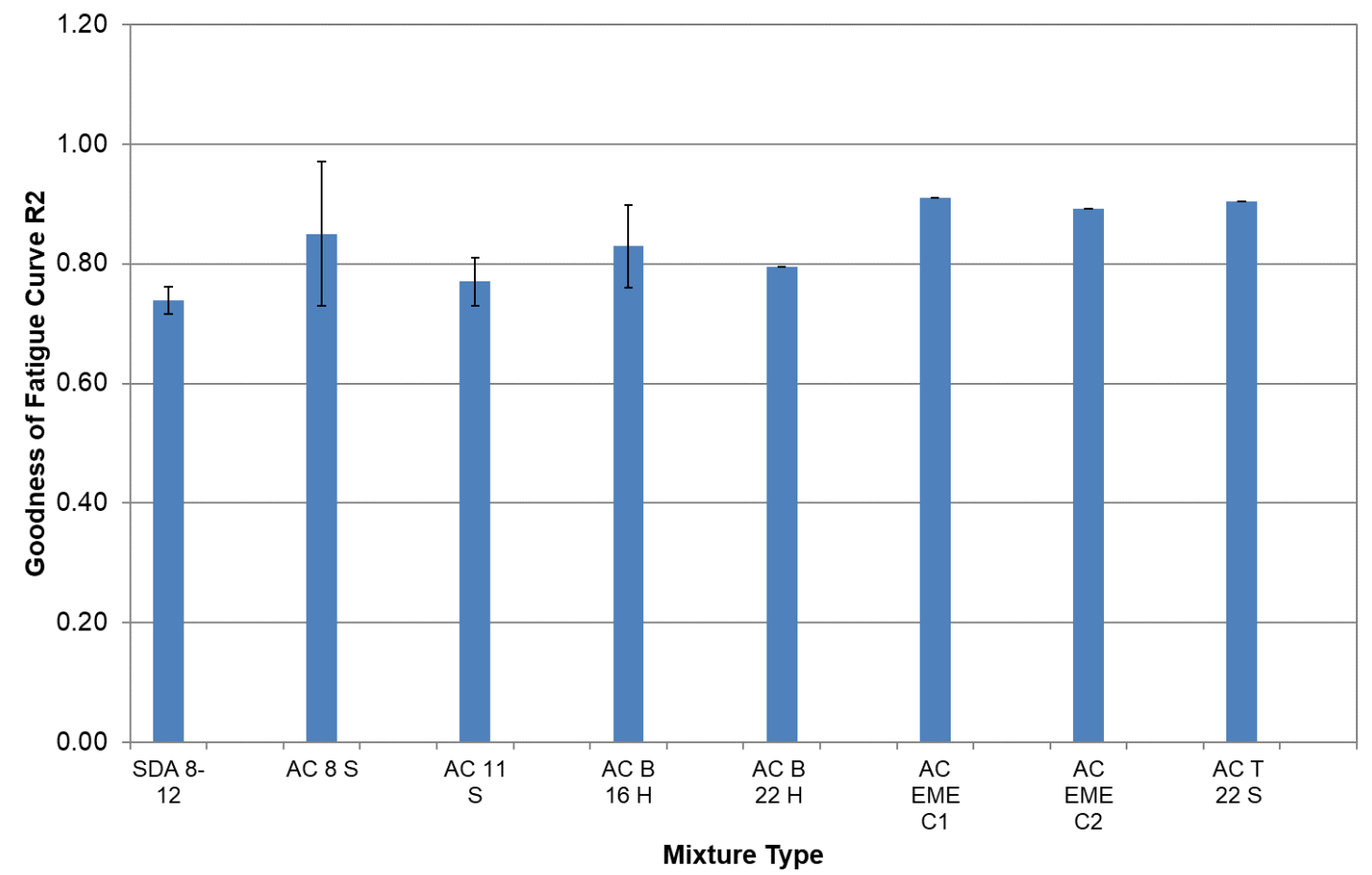

Figure 5 Goodness of fatigue curve with respect to mixture type using 4PB-PR and CIT-CY tests

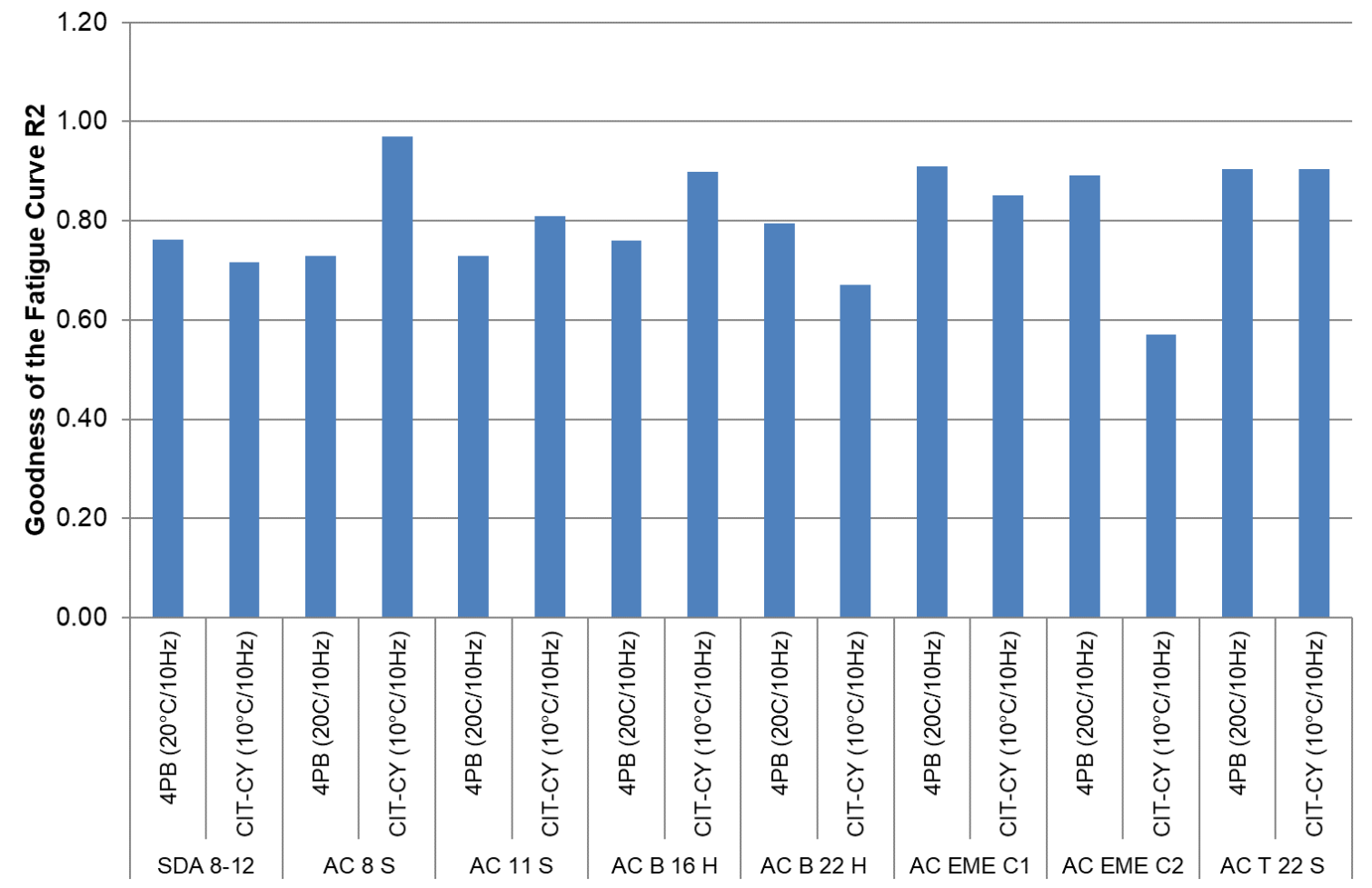

Figure 6 Goodness of fatigue curve with respect to test type 
From the results, it can be concluded that the 4PB-PR and IC-TY do not give the same values for fatigue resistance and fatigue behavior in general. The 4PB-PR tests induce bending and therefore are a more realistic indication of fatigue while the IC-TY tests induce tension and compression.

\section{Summary and Conclusions}

For the stiffness modulus and fatigue tests from eight plant produced mixtures a total of 303 prismatic and cylindrical samples were prepared and tested.

Various tests procedures delivered different results as there is intrinsic bias in the test methods. This is on the one hand due to the testing mechanisms and on the other due to the type testing parameters of temperature and frequency. However, the trend and ranking of the materials for modulus tests, for a majority of cases studied, was similar for 4PB-PR and CIT-CY regardless of the temperatures and testing devices. Therefore, both these test methods are recommended for determination of stiffness modulus.

IT-CY modulus tests performed on eight mixtures did not show sensitivity to the mixture type as much as the other tests that use a sinusoidal continuous force application. The results of ITCY also did not follow the same trend as the 4PB-PR and CIT-CY. This could be attributed to the pulse form of the applied load with a resting period that allows the material to recover between load applications. Therefore, IT-CY is not recommended for modulus tests.

Production of 4PB-PR samples requires larger samples and more material.

IT-CY fatigue tests require a much longer testing period (for 9 samples) in comparison to 4PB-PR and CIT-CY

4PB-PR tests induce symmetric bending and therefore are a more realistic indication of fatigue. The results obtained in this work indicate that the fatigue resistance values obtained with the 4PB-PR test reflect the expectations from practice more closely than CIT-CY and 
therefore 4PB-PR is recommended as a preferred test method given material and time is available.

Fatigue curve goodness value R2 does not systematically depend on type of test or type of mixture. Based on the results for the fatigue curves, an R2 value of at least 0.75 is recommended.

Results obtained from the 4PB-PR tests showed that the AC mixtures with NMAS=22mm had the lowest fatigue resistance. Whereas the AC EME mixtures with NMAS=22mm performed similar to AC mixtures of lower NMAS.

\section{Acknowledgements}

The authors gratefully acknowledge the Federal Roads Office (FEDRO/ASTRA) through VSS for the financial support, grant number VSS 2014/502. The contributions of the accompanying commission (BK) for the choice of mixtures and evaluation of the obtained results is acknowledged. The technical support from the Road Engineering/Sealing Components lab at Empa in preparing samples and performing a minimum of 303 tests is gratefully acknowledged. The cooperation of the company Laboroute in obtaining some mixtures and discussions is acknowledged.

\section{References}

Asphaltmischgut Mischgutanforderungen teil 20: Erstprüfung Nationaler Anhang zu EN 13108-20:2006/AC:2008

Bituminous mixtures- material specifications- part 1: Aspahlt concrete National Annex. Asphaltmischgut- Mischgutanforderungen-teil 1: Asphaltbeton; nationaler Anhang

EN 12697-24 Bituminous mixtures - Test methods for hot mix asphalt - Part 24: Resistance to fatigue (July 2007)

EN 12697-26 Bituminous mixtures - Test methods for hot mix asphalt - Part 26: Stiffness (March 2012)

EN 12697-1:2012Bituminous mixtures - Test methods for hot mix asphalt - Part 1: Soluble binder content

EN 12697-3, Bituminous mixtures - Test methods for hot mix asphalt — Part 3: Bitumen recovery: Rotary evaporator

SN EN 13108-20-NA: 2006/AC:2008 Asphaltmischgut Mischgutanforderungen Teil 20: : Erstprüfung Nationaler Anhang (National Annex type testing) 
EN 12697-22-2003 Bituminous mixtures - Test methods for hot mix asphalt - Part

22: Wheel tracking

Francken, L., editor, 1998. Bituminous Binders and Mixes. Rilem report 17. Printed by E \& FN Spon

Nejad, F.M., Aflaki, E., Mohammadi, M.A. Fatigue behavior of SMA and HMA mixtures (2010) Construction and Building Materials, 24 (7), pp. 1158-1165.

Mikhailenko, P., Ataeian, P. \& Baaj, H. Extraction and recovery of asphalt binder: a literature review. Int. J. Pavement Res. Technol. 13, 20-31 (2020). https://doi.org/10.1007/s42947019-0081-5

Pasetto, M., Baldo, N. Mix design and performance analysis of asphalt concretes with electric arc furnace slag (2011) Construction and Building Materials, 25 (8), pp. 3458-3468.

Poulikakos, L.D., dos Santos, S., Bueno, M., Kuentzel, S., Hugener, M., Partl, M.N. Influence of short and long term aging on chemical, microstructural and macro-mechanical properties of recycled asphalt mixtures (2014) Construction and Building Materials, 51, pp. 414-423.

Poulikakos L.D., Standardization requirements for the Swiss annex to EN for stiffness modulus and resistance to fatigue Forschungsprojekt VSS 2014/502 auf Antrag des Schweizerischen Verband der Strassen- und Verkehrsfachleute (VSS), report Nr 1660, 2019, www.astra.admin.ch

Puchard, Z., Gorgenyi, A., Hungarian experience with different bending devices (2012). FourPoint bending. Pais and Harvey editors Taylor and Francis Group London

Di Benedetto, H., C. de La Roche, H. Baaj, A. Pronk and R. Lundstrom (2004). "Fatigue of bituminous mixtures." Materials and Structures 37(267): 202-216.

Eberhardsteiner, L. and R. Blab (2017). "Design of bituminous pavements - a performancerelated approach." Road Materials and Pavement Design 20(2): 244-258.

Hofko, B., R. Blab and M. Mader (2012). Impact of air void content on the viscoelastic behavior of hot mix asphalt. Four Point Bending. J. Pais and J. Harvey. Leiden, CRC Press/Balkema: 139.

Poulikakos, L. D., M. Pittet, A. G. Dumont and M. N. Partl (2014). "Comparison of the two point bending and four point bending test methods for aged asphalt concrete field samples." Materials and Structures/Materiaux et Constructions 48(9): 2901-2913.

Rahbar-Rastegar, R. and J. S. Daniel (2019). "Laboratory versus plant production: impact of material properties and performance for RAP and RAS mixtures." International Journal of Pavement Engineering 20(1): 61-72.

Steiner, D., B. Hofko and R. Blab (2016). Effect of Air Void Content and Repeated Testing on Stiffness of Asphalt Mix Specimen. CIVIL ENGINEERING CONFERENCE IN THE ASIAN REGION CECAR 7, Waikiki, USA. 